\title{
Biological control of tomato wilt disease incited by Fusarium oxysporum f.sp lycopersici and there effects on seed germination and other biological parameters
}

\author{
O. I. Saleh*, M. R. Gabr*, M. A. Khalil** and E. I. Mohamed** \\ "Plant Pathology Dept., Fac. Agric. El-Minia Unv. Egypt. \\ *Plant Pathology Res. Institute, Agric. Research Center, Giza, Egypt. \\ Corresponding author: salehelkhashab@gmail.com
}

\begin{abstract}
In previous paper it has been reported that Fusarium oxysporum f.sp lycopersici was the incident of Fusarium wilt disease in some Egyptian governorates (Saleh et al., 2016).This paper delt with biological control of the pathogenic fungus. Trichoderma harzianum, Trichoderma viride, Bacillus subtilis and Bacillus megaterium were isolated from rhizospher of naturally wilted infect plant and identified as abovementioned . The bioagents showed strong antagonistic effect in vitro and reduced disease severity under filed conditions. T. harzianum proved more powerful than $T$. viride in reducing disease severity while $B$. subtilis proved slightly more powerful than $B$. megaterium under this investigation. Moreover, T. harazianum, B. subtilis and Rhizo - $\mathrm{N}$ were more powerful indecreasing disease severity than other tested bioagents and surpassed the plant - guard and Moncren fungicide. Culture filtrate of Fusarium oxysporum $\mathbf{f}$. sp Lycopersici reduced seed germination of tomato and affected other botanical parameters indicating that it is hazardous and notorious.
\end{abstract}

Keywords: Fusarium oxysporum f.sp Lycopersici, Trichoderma spp, Bacillus ssp, Rhizo - N., Plant Guard ., Monceren Compy.

\section{Introduction}

Tomato (Lycopersicon esculentum Mill) is an economically important vegetable crop in Egypt (Ministry of Agricultural and Soil Reclamation, 2015). It is commonly grown by vegetable growers word wide(Jacobs et al., 2013). Fusarium oxysporum f. sp lycopersici is an abundant in Egypt and cause severe losses in yield (Saleh et al., 2016)

The soil - borne tomato root infecting pathogen Fusarium oxysporum f. sp lycopersici is particularly difficult to control using standard cultural and chemical methods (chandel et al., 2009). Wilt resistant varieties of tomato are available but resistant has been overcome by the appearance of new races of the pathogen. Moreover, synthetic pesticides are costly, pollute the environment and are potentially harmful to animal and humans. Furthermore, their repeated use promotes the development of chemically resistant strains (Vinale et $\boldsymbol{a l}$., 2014 ). The use of microbes for pest management in agriculture of biological control may be attractive .The use of microbial community in the rhizospher may suppress pathogens, overall improvement of plant health, growth promotion, increased nutrient availability and uptake and enhanced host resistant to both biotic and a biotic stress (Hartman, 2000, Vinale et al., 2014 and Chandel et al., 2009). The antagonistic activity to pathogens of many soil microorganism including, Trichoderma , Gliocladium, non - pathogenic Fusarium spp., Bacillus spp ., Psedomonas spp ., Burkhoderia and has resulted in new products in biological control of soil born plant pathogens becoming established ( Datroff $\boldsymbol{e t}$ al., 1995, De Cal $\boldsymbol{e t}$ al., 1995, Larkin and Fravel 1998 and Fravel et al ,2005).Again Free - culture filtrates of $T$. harazianum , T. viride and T. longibrachianum reduced fungal growth of Fusarium solani and Fusarium oxysporum f. sp lycopersici (Enespa and Dwivedi , 2014 , and Sabry - Soha et al., 2016).

Culture filtrates of Fusarium oxysporum f. sp lycopersici reduced the seed germination and affected some growth parameters of tomato( Lim et al ., 1990 ,Idris et al ., 2003 and kurshid, et al ., 2014).

The objective of this investigation was to isolate some bioagents from naturally wilted tomato plants, to identify them evaluating of their role as biological agents.The effect free culture filtrates of the bioagents on growth of the pathogenic fungus was studied Furthermore, free culture filtrate of the pathogenic fungus was tested on seed germination of tomato and some growth parameters.

\section{Materials And Methods}

\section{Source of pathogenic fungal isolates}

Eight fungal isolates which proved pathogenic and representing different localities in different governorates,i.e.Behera,Minofiya, Ismailia and Minia were isolated from wilted tomato plants and investigated and identitied as Fusarium oxysporum f. sp.lycperisci .Pthogenicity test revealed El -Katatba isolate(Minofiya Governorate) was the most virulent(Saleh et al.,2016).

\section{Effect of different concentrations of fungicide on the linear and amount of growth of the tested fungi in vitro:}

The effect Monsrean fungicide (active ingredient $25 \%$ Pencycuron) was estimated by measuring the linear growth and amount of growth obtained on the treated as well as untreated PDA medium. The tested fungicide was incorporated into the growth medium at 
50, 100 and $150 \mathrm{ppm}$ (final concentrations). Inoculation was carried out using equal discs of five millimeter obtained from 4 days old culture (grown on PDA medium).Incubation was performed at 30C for one week. The formula suggested by Fokemmma (1973) was used to determine growth inhibition as follow:

Reduction of mycelia growth $=\mathrm{R}_{1}-\mathrm{R}_{2}$ X 100

$\mathrm{R}_{1}$

Where $\mathrm{R}_{1}=$ the radius of normal growth in control plate.

$\mathrm{R}_{2}=$ the radius of inhibited growth.

\section{2: Isolation of the antagonisitic agent:}

This experiment was performed to isolate the native microflora in the rhizosphere of naturally wilted tomato plants that may antagonize the pathogenic fungi causing wilt disease of tomato. Naturally diseased plants were collected from different fields in Minia Governorate. Isolation of the bioagents were performed as described by $\operatorname{Saleh}(1997)$.

In vitro evaluation of Bioagent(fungi and bacteria) and identification:

A: Fungi:

The antagonistic effect of the isolated fungi was subsequently confirmed as described by( Chang and Komedahl, 1968, and Saleh,1997. Antagonistic fungi were purified by single spore method .Bacteria were purified by subculturing many times to ensure purity. Idintification of fungi was verified by Assuit University Mycological Institute (AUMI). The given identification revealed that the isolated fungi belongs to Trichoderma harzianum and Trichoderma viride.Bacterial isolates that showed strong antagonistic effect aginast the pathogenic fungus $(F$. oxysporium f. sp lycopersici) were evaluated for their antagonistic by the method described by Change and Kommed 1968 and Saleh,1997. Isolates of bacteria that gave strong anatagonistic effect were then identified by Bacterial Plant Disease Department, , Plant Pathology Institute Agriculture Research Center. The givin idefication revealed that the bacterial isolates belong to Bacillus subtilis and Bacillus megaterium.

Preparition of the inocula of pathogenic fungal isolate and antagonistic fungi:

\section{1.: Fungi:}

The inoculum of the pathogenic fungus $F$. oxysporium $\mathrm{f}$. sp lycopersici was prepared according to Saleh et al.,( 2016) by mixing inoculated sorghum grains with soil that previously inoculated with The inocula of antagonistic fungi of $T$. harzianum and $T$. viride individually in sterile soil one week before soil infestation with the pathogenic fungus ( $F$. oxysporium f. sp lycopersici) at 3\% w/w (Chang and Komedhal 1968). One week later they were trasplated with seedlings in wet pots( four pots were used for each treatment(four transplants/pot). Super strain B cultivar was used through this investigation.

\section{2: Preparation of antagonistic bacteria:}

Bacterial isolates $\mathrm{i}$ e Bacillus subtilis. and $B$. megaterium were inoculated inidividually into conical flasks $250 \mathrm{ml}$ containing $100 \mathrm{ml}$ PD broth, incubated at $27^{\circ} \mathrm{C}$ for 2 days and used for inoculation . Root system of transplants (cv super strain B ) were dipped in bacterial suspension for half houre, after which they were transplanted directly in wet pot. Four replicates (pots) were used and 4 seedlings /pot. Two controls were used, the first control treatment was performed in simillar manner but without emerging root system of transplants in bacterial suspension in infested soil with the pathogenic fungus $F$. oxysporium f. sp lycopersici. The second one was performed using sterile soil without fungal inocula. Seedlings of the above mentianed cultivar were transplanted and irrigated directly and subsequently when necessary.

As for Rhizo-N (30 million cell/g of B. subtilis) of $3 \mathrm{~g} / \mathrm{L}$ was dissolved in sterile water and seedling roots of used transplants were dipped for half houre and transplanted in infested soil and treated as above( as recommended by manufacture).

As for Plant-Guard (30 million spores/ml a biological compound of viable spores of Trichoderma harzianum) a volume of $4 \mathrm{ml}$ was aseptically added to one liter and roots of seedling were dipped for half hours and treated as above (as recommended by manufacture).The fungicide Moncrean (25\% Pencycuron) was also used at $3 \mathrm{~g} / \mathrm{L}$ for comparison. Root system of seedling of the abovemenation tomato cultivar were also dipped in the fungicide for half hour and treated as above. Data were recorded 10, 20,30, days after transplanting. Disease severity was recorded as mentioned before (Saleh $\boldsymbol{e t}$ al., 2016).

Effect of culture filtrates of different bioagent on the growth and dry weight of of the pathogenic fungi.

4.1.1: Preparation of free culture filtrates.

Briefly, conical flasks $250 \mathrm{ml}$ each containing $100 \mathrm{ml} \mathrm{PD}$ broth(P was inoculated with $0.5 \mathrm{~cm}$ fungal disc of either $T$. harzianum and $T$. viride and incubated at $30^{\circ} \mathrm{C}$ for 7 days. Fungal growth was harvested by filtration. Crude culture filtrates was filter sterilized through Sartorius Minister (E Millipore filter $0.2 \mu \mathrm{m})$. The tested antagonistic bacteria were inoculated individually in PD broth using a bacterial loap of 24 hour old. Culture incubation was performed at $30^{\circ} \mathrm{C}$ for 2 days. Sterile culture filtrates were prepared as above.

The effect of culture filtrates of $T$. harazianum, $T$. viride, B. subtilus and B.s megaterium on mycelial growth and dry weight of the tested fungus was investigated. The technique described by Enespa and Dwivedi (2014) was used and the percentage of reduction in fungal growth was calculated using the 
formula suggested by Fokemmma (1973) as mentioned before.

A volume of $2.5,5.0$ and $10 \mathrm{ml}$ of sterile culture filtrate of either bioagent was added individually to 97.5, 95 and $90 \mathrm{ml}$ of PDA at about $45^{\circ} \mathrm{C}$ to give final volume $100 \mathrm{ml}(2.5,5$ and $10 \% \mathrm{~V} / \mathrm{V})$. Three replicates were used for each treatment. Petri dishes and flasks were inoculated with $0.5 \mathrm{~cm}$ disc of pathogenic fugus and incubated (at $27^{\circ} \mathrm{C}$ ) for seven days, after which period mycelial radius growth was measured as before. Mycelia was harvested and dry weight was determined. Regarding Rhizo-N commercial product (Bacillus subtilus) formulation a loap of Rhizo-N was added aseptically to $100 \mathrm{ml}$ PD broth and incubated for two days and tested as above. Inhibition of the growth and dry weight was calculated as previously described. Regarding Plant-Guard (the commercial product of $T$. harazianum) a volume of $10 \mathrm{ml}$ was added aseptically to $90 \mathrm{ml}$ potato dextrose broth and incubated at $27^{\circ} \mathrm{C}$ for seven days. This was followed by filtration through Watman filter paper $(9.0 \mathrm{~cm}$ diameter) and filter sterilized by millipore filter as previously described. The rest of the procedures were achieved as previously described.

Effect of sterile culture filtrates of the tested fungus ( $F$. oxysporium f. sp lycopersici) on seed germination and other botanical parameters:

Ten surface sterilized tomato seeds of Super Strain B were placed on sterile filter paper on sterile Petri dish. Subsequently, a volume of 2.5, 5.0 and $10 \mathrm{ml}$ of sterile culture filtrate of the tested fungus was added aseptically. Control treatment was carried using sterile water in similar manner. Plates were incubated at room temperature. $\left(27^{\circ} \mathrm{C}\right)$ and scanned daily. After seven days, the percentage of seed germination, length of root and hypocotyle were recorded (Saleh and Stead, 2003).

\section{6: Statistical analysis.}

Data were subjected to statistical analysis of variance. The experimental design (S) of all studies was a completely randomized with three or four replications, analysis of variance (ANOVA) of the data was performed with the MSTAT-C statistical package (A) micro-computer program for the design, management, and analysis of agronomic research experiments. Michigan State Univ., USA. Least significant difference (LSD) was used to compare treatment means (Gomez and Gomez, 1984).

\section{RRESULTS}

Effect of different concentrations of Moncrean fungicide on mycelial linear and dry weight of the tested fungi in vitro:

The effects of Moncrean fungicide on growth of the isolates tested are shown in Table (1) and Figs. (8 and 9). The obtained results showed that the different concentrations of the fungicide significantly decreased both of mycelial radial growth and amount of growth of all tested isolates.

All concentrations of Moncren checked mycelial linear growth and dry weight of the tested fungal isolates (Table 1). Dose of Moncrean which caused complete inhibition to fungal linear growth was 150 ppm. Whereas, this concentration of the fungicide achieved $85.1-98.4 \%$ inhibition of dry weight depending on the tested fungal

Table 1. Toxicity of Monceren fungicide (PPM) against diferent isolates of Fusarium oxysporum $\mathrm{f}$. sp. lycopersici on PDA and PD medium.

\begin{tabular}{|c|c|c|c|c|c|c|c|c|c|c|}
\hline \multirow{3}{*}{$\begin{array}{l}\text { Fungal } \\
\text { isolates } \\
\text { (A) }\end{array}$} & \multicolumn{10}{|c|}{ Active ingredient ppm (B) Inhibition (\%) } \\
\hline & \multicolumn{5}{|c|}{ linear growth } & \multicolumn{5}{|c|}{ dry weight } \\
\hline & $\begin{array}{c}\text { Control } \\
0.0\end{array}$ & $\begin{array}{c}\mathbf{5 0} \\
\text { ppm }\end{array}$ & $\begin{array}{l}100 \\
\text { ppm }\end{array}$ & $\begin{array}{c}150 \\
\text { ppm }\end{array}$ & Mean & $\begin{array}{c}\text { Control } \\
0.0\end{array}$ & $\begin{array}{c}50 \\
\text { ppm }\end{array}$ & $\begin{array}{r}100 \\
\text { ppm }\end{array}$ & $\begin{array}{c}150 \\
\text { ppm }\end{array}$ & Mean \\
\hline 1 & 0.0 & 63.9 & 87.4 & 100 & 83.3 & 0.0 & 30.8 & 63.2 & 92.2 & 54.2 \\
\hline 2 & 0.0 & 61.7 & 77.8 & 100 & 79.8 & 0.0 & 20.1 & 58.3 & 85.1 & 59.8 \\
\hline 3 & 0.0 & 81.9 & 91.9 & 100 & 91.3 & 0.0 & 62.5 & 79.2 & 98.1 & 64.7 \\
\hline 4 & 0.0 & 79.7 & 86.7 & 100 & 84.1 & 0.0 & 55.3 & 79 & 93.9 & 80 \\
\hline 5 & 0.0 & 69.5 & 77.7 & 100 & 82.4 & 0.0 & 40 & 71.5 & 90 & 65.5 \\
\hline 6 & 0.0 & 64.2 & 88.2 & 100 & 88.8 & 0.0 & 35.3 & 56.2 & 87.9 & 76 \\
\hline 7 & 0.0 & 77.8 & 86.7 & 100 & 88.2 & 0.0 & 55.2 & 71.1 & 96.2 & 74.1 \\
\hline 8 & 0.0 & 72.2 & 86.1 & 100 & 86.1 & 0.0 & 44.3 & 57.5 & 92.3 & 49.2 \\
\hline L.S.D at $0.05 \%$ & \multicolumn{5}{|c|}{$\begin{array}{c}(\mathrm{A})=3.1 \\
(\mathrm{~B})=\mathbf{1 . 5} \\
(\mathrm{AXB})=\mathbf{4 . 3}\end{array}$} & \multicolumn{5}{|c|}{$\begin{array}{c}(\mathrm{A})=6.4 \\
(\mathrm{~B})=4.2 \\
(\mathrm{AXB})=11.8\end{array}$} \\
\hline
\end{tabular}

\section{In vitro and in vivo evaluation of bioagents:}

.Results in Table (2) of in vitro study showed that both Trichoderma harzianum and Trichoderma viride appeared to be antagonistic to the isolated fungus. This was expressed by their overgrowth on the obtained pathogenic fungus. Plant-Guard also inhibited the mycelial growth of the pathogenic fungus.As for both Bacillus subtilis and Bacillus megaterium showed strong antagonistic effect against the tested pathogenic fungus (Fig 1 and 2). Which may be due to their production of antibiotic compounds. $B$. subtilis was inhibited the mycelial growth by about 
32.4\%. Similar results were obtained with $B$. megaterium (Fig. 1) since it inhibited the mycelial growth of the fungus by about $48.7 \%$.

Again, Rhizo-N (Fig.3) which showed similar strong antagonistic effect since it inhibited mycelial growth by 54.2. Concerning, T. harazianum and
T.viride they overgrew the tested pathogenic fungus and inhibited mycelial growth by100.Again, PlantGuard which is the commercial product of $T$. harazianum showed similar effect and inhibited mycelial growth of the pathogenic fungs by $100 \%$.

Table 2. Antagonistic effect of some microorganisms on virulent isolates of F.oxysporum $\mathrm{f}$. sp lycopersici in vitro (Calculated as \% of inhibition of mycelial growth).

\begin{tabular}{lc}
\hline \multicolumn{1}{c}{ Bioagent } & $\begin{array}{c}\text { \% inhibition of the mycelial growth } \\
\text { of the virulent isolate }\end{array}$ \\
\hline Trichoderma harzianum & 100.0 \\
\hline Trichoderma viride & 100.0 \\
\hline Bacillus subtilis & 32.4 \\
\hline Bacillus megaterium & 48.7 \\
\hline Plant guard $($ T. harzianum) & 100.0 \\
\hline Rhizo- $\boldsymbol{N}($ B. subtilis $)$ & 54.2 \\
\hline Control & 0.00 \\
\hline L.S.D at $\mathbf{0 . 0 5 \%}$ & 6.2 \\
\hline
\end{tabular}

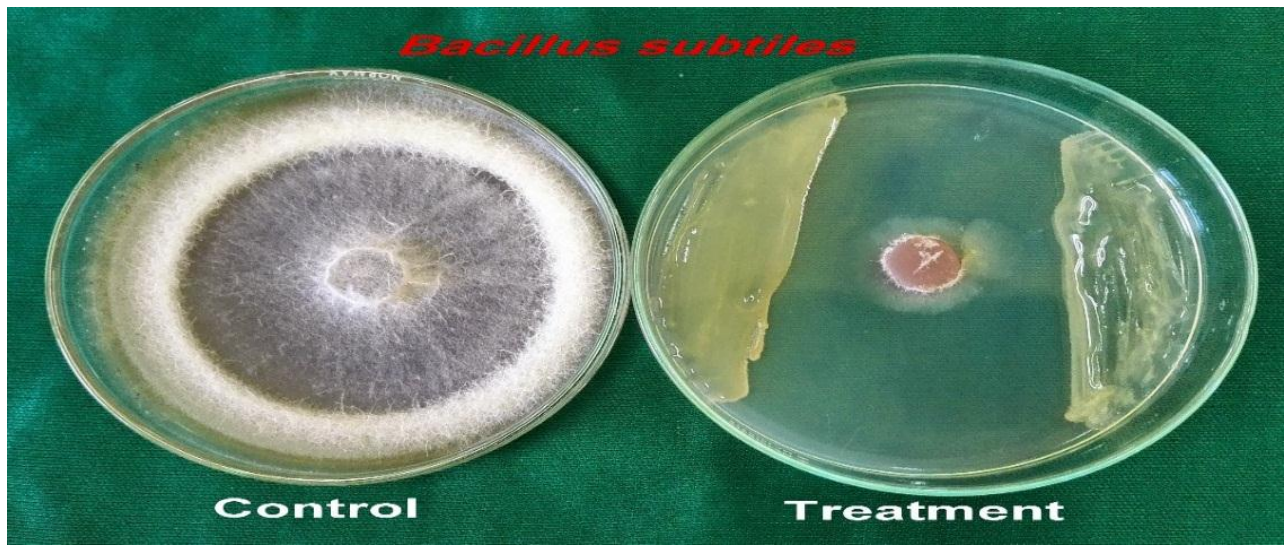

Fig. 1 Antagonistic effect of Bacillus subtilis against the most virulent isolate of $F$. oxysporum f. sp lycopersici in vitro Elkattba Minofiya.

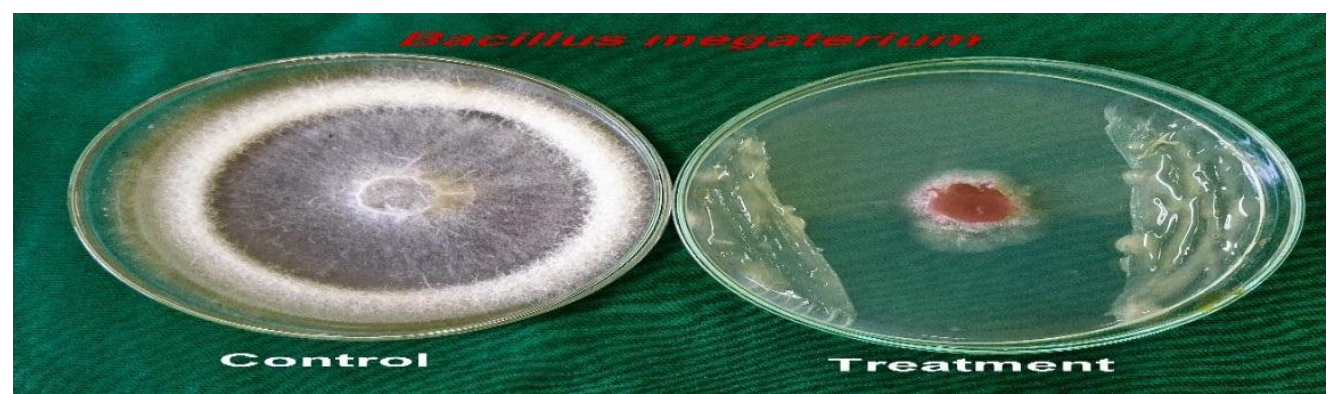

Fig. 2 Antagonistic effect of Bacillus megaterium against the virulent isolate of $F$. oxysporum f. sp lycopersici in vitro.

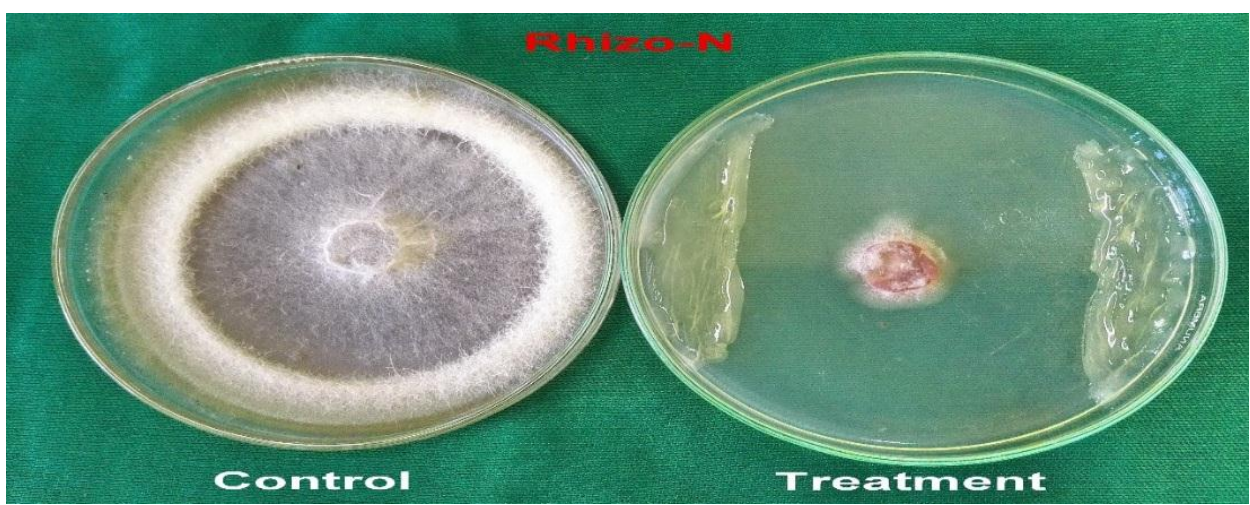


Fig. 3 Antagonistic effect of Rhizo-N against the virulent isolate of $F$. oxysporum $\mathrm{f}$. sp lycopersici in vitro.

1.2 The evaluation of the bioagents and fungicide against $\boldsymbol{F}$. oxysporum f. sp lycopersiscii:

Results in Table (3) reveal that the application of either B. subtilis or B. megaterium to artificially infested soil with $F$. oxysporum f.sp lycopersici was decreased the disease severity by 78.3 and 72.9 respectively. B. subtilis proved slightly more powerful than B. megaterium in decreasing the disease severity during 2014 growing season. It approached the effect of Rhizo-N in decreasing, the disease severity. The reverse is true regarding effect of $B$. megaterium during 2015 growing season. The interesting point is that the effect of $B$. subtilis and $B$. megaterium approached the effect of Rhizo-N in decreasing disease severity. Again the effect of B. subtilis and B. megaterium surpassed the effect of Moncren fungicide. Similar trend of results were obtained regarding vascular browing in both two tested seasons. As for the effect of either T. harzianum or $T$. viride they decreased the disease severity of the tested pathogenic fungus. Moreover, T. harzianum proved more powerful in decreasing disease severity than T.viride since it decreased disease severity by about 70.4 compared with $15.4 \%$ during 2014 growing season. Variable results were obtained during 2015 growing season. The interesting point is that the effect of $T$. harzianum in decreasing disease severity surpassed the effect of Plant-guard and the Monceren fungicide. In general, the effect of some isolated bioagents in this investigation proved promising in decreasing disease severity of the tested fungi and may be used as formulation.

Table 3. Effect of some bioagents and commercial ones on the reduction of disease severity of Fusarium oxysporum f. sp. lycopersici on tomato under greenhouse condition.

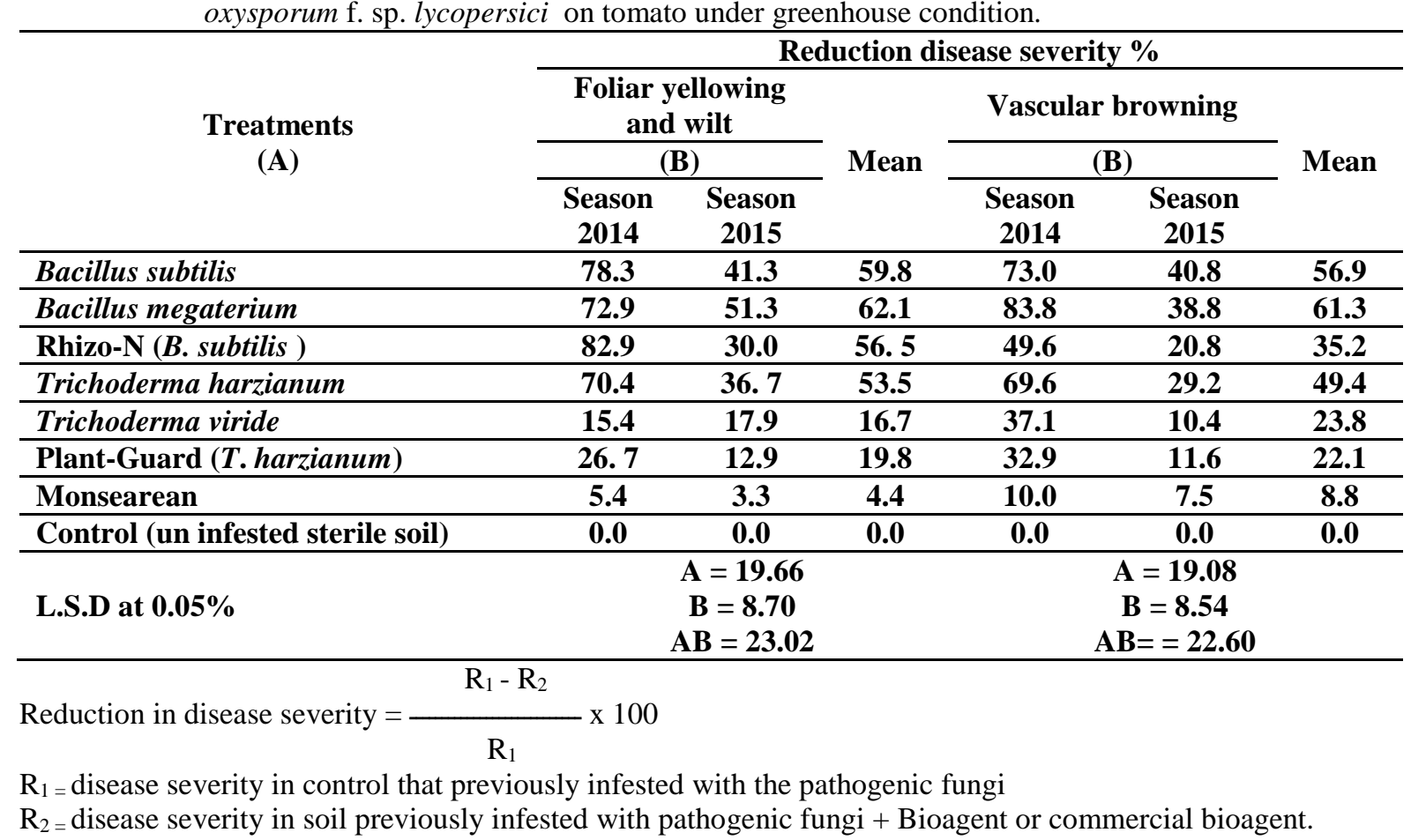

\section{Effect of culture filtrates:}

3.1. Effect of sterile culture filtrates of different bioagent on mycelial growth and mycelial dry weight on Fusarium oxysporum f. sp. lycopersici :

Data in Table (4) and Figs. (4,5.6,7,8 and 9 ) show the effect of culture filtrate on the most pathogenic isolate. The obtained data show that concentration of free culture filtrates of different bioagents significantly decreased in most cases mycelia radial growth and dry weight of the tested fungus (Table 4).

Also, the commercial product of Plant-Gard (Trichoderma harazianum) was significantly decreased mycelial linear growth and dry weight of the tested fungus. As for Rhizo-N also decreased mycelia radial growth and dry weight of the tested fungus particularly that of dry weight. It could be stated that free culture filtrate of the isolated bioagents, $T$. harazianum, T. viride, B. subtilis and $B$. megaterium are effectively powerful in decreasing fungal linear and dry weight of the fungus and surpassed in some cases effect of either Rhizo-N and plant-Gard. 
Table 4. The effect of culture filtrate of different Bioagnet in comparison with some available commercial products on mycelial linear and dry weight of Fusarium oxysporum f. sp lycopersici.

\begin{tabular}{|c|c|c|c|c|c|c|c|c|}
\hline \multirow{3}{*}{$\begin{array}{l}\text { Bioagnet and commercial } \\
\text { product }(\mathrm{A})\end{array}$} & \multicolumn{8}{|c|}{ Concentration of Bioagnet \% of inhibition (B) } \\
\hline & \multicolumn{4}{|c|}{ mycelial linear growth } & \multicolumn{4}{|c|}{ mycelial dry weight (mg) } \\
\hline & $2.5 \%$ & $5 \%$ & $10 \%$ & Mean & $2.5 \%$ & $5 \%$ & $10 \%$ & Mean \\
\hline Trichoderma harazianum & 70 & 80 & 100 & 83.3 & 66.7 & 71.4 & 100 & 79.4 \\
\hline Trichoderma viride & 62.5 & 67.5 & 95 & 67.1 & 52.8 & 58.4 & 85.5 & 63.9 \\
\hline Plant-Guard & 60 & 66.3 & 87.5 & 71.3 & 61.1 & 68.3 & 76.5 & 68.6 \\
\hline Bacillus subtilis & 58.8 & 62.5 & 80 & 67.1 & 36.1 & 47.2 & 63.9 & 49.1 \\
\hline Bacillus megaterium & 40 & 45 & 67.5 & 50.8 & 19.5 & 26 & 31.8 & 25.7 \\
\hline Rhizo-N & 48.8 & 52.5 & 75 & 58.8 & 27.2 & 33.3 & 44.4 & 35 \\
\hline Control & 0.0 & 0.0 & 0.0 & 0.0 & 0.0 & 0.0 & 0.0 & 0.0 \\
\hline L.S.D at $0.05 \%$ & \multicolumn{4}{|c|}{$\begin{aligned}(\mathrm{A}) & =4.5 \\
(\mathrm{~B}) & =2.4 \\
\mathrm{AXB} & ==5.8\end{aligned}$} & \multicolumn{4}{|c|}{$\begin{aligned}(\mathrm{A}) & =4.5 \\
(\mathrm{~B}) & =2.4 \\
\mathrm{AXB} & ==5.8\end{aligned}$} \\
\hline
\end{tabular}

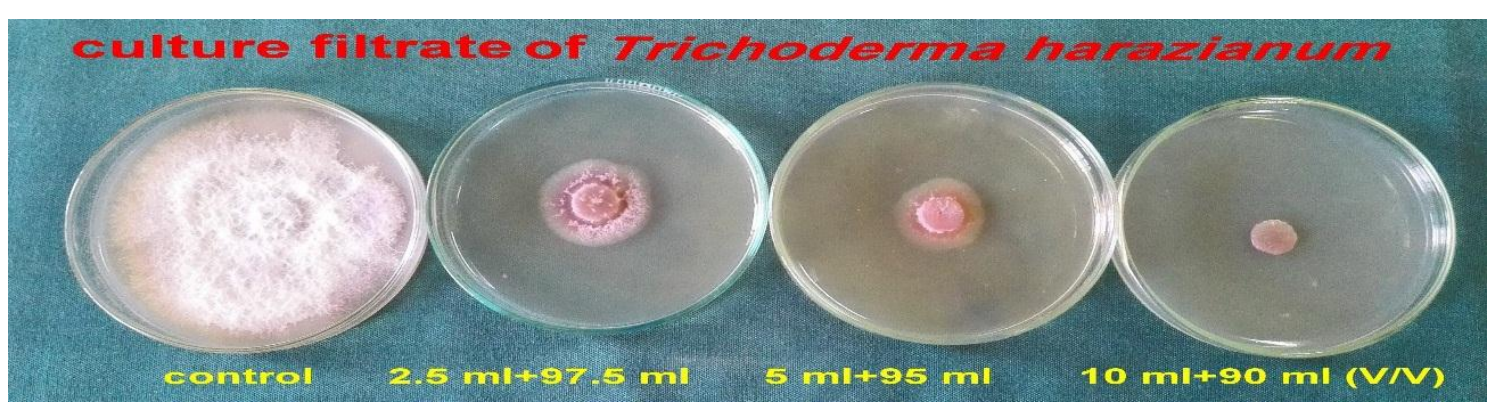

Fig. 4 Effect of culture filtrates of Trichoderma harzianum on growth of F. oxysporum f. sp lycopersici.

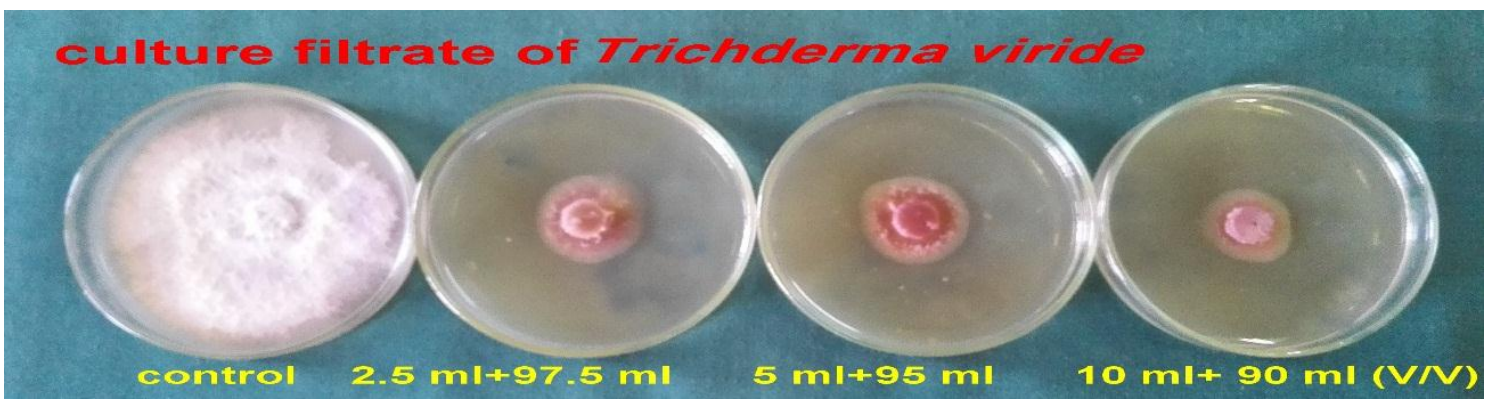

Fig. 5 Effect of culture filtrates of Trichoderma viride on growth of F. oxysporum f. sp lycopersici.

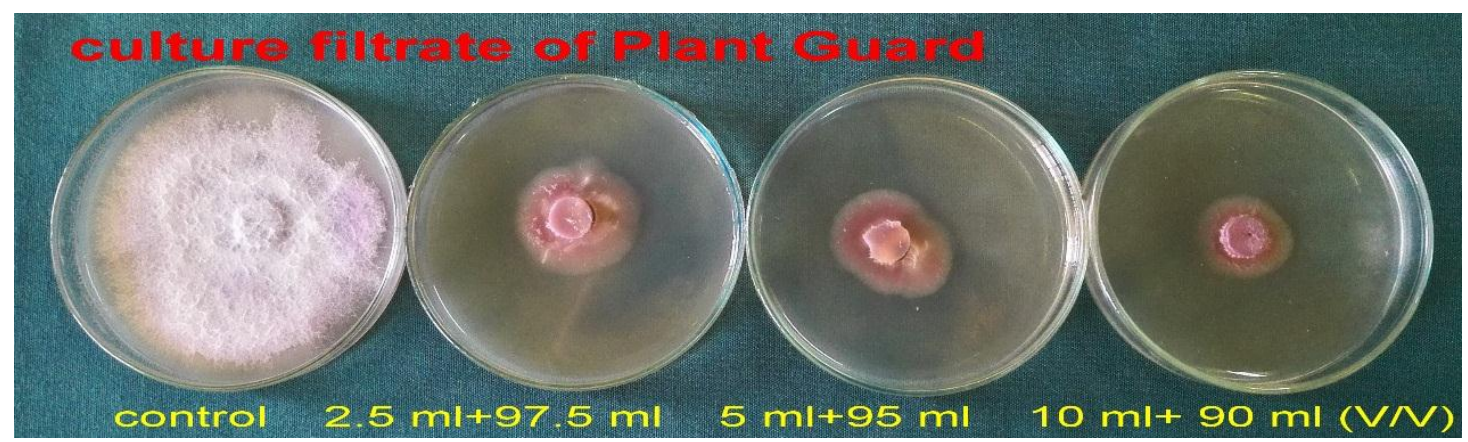

Fig. 6 Effect of culture filtrates of plant-Gard on growth of $F$. oxysporum $\mathrm{f}$. sp lycopersici. (Most virulent isolate) 


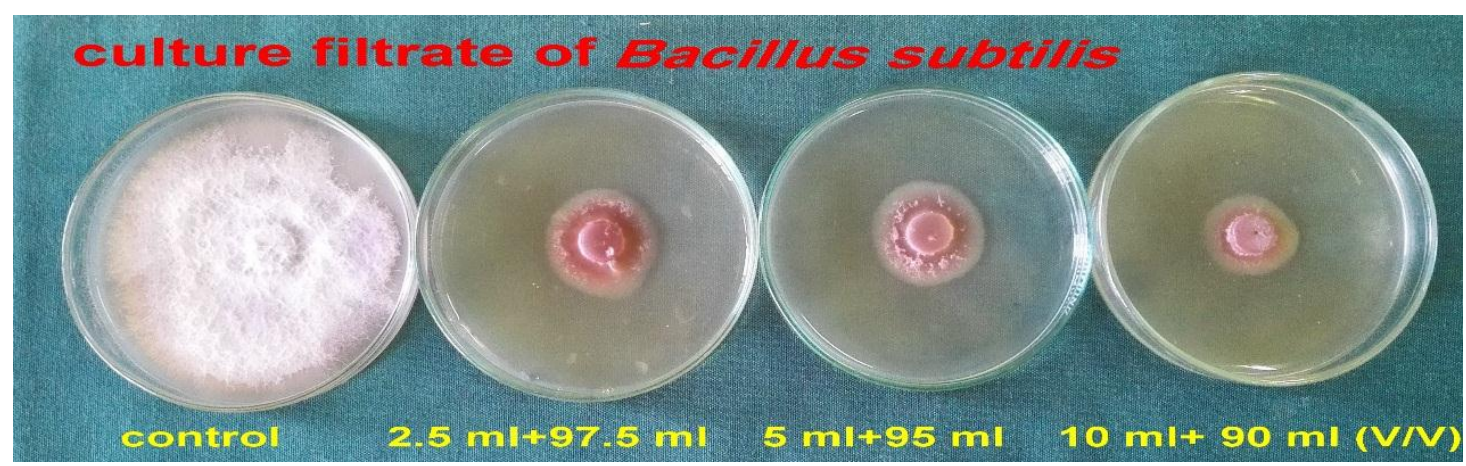

Fig. 7 Effect of culture filtrates of Bacillus megaterium on growth of F. oxysporum f.sp lycopersici.

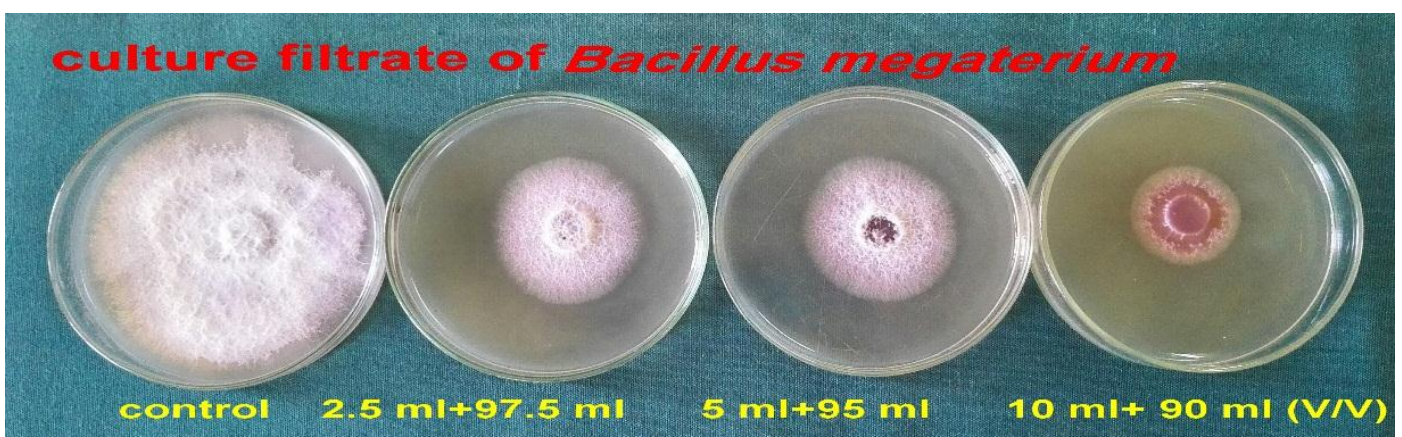

Fig. 8 Effect of culture filtrates of Bacillus subtilis on growth of $F$. oxysporum f.sp lycopersici.

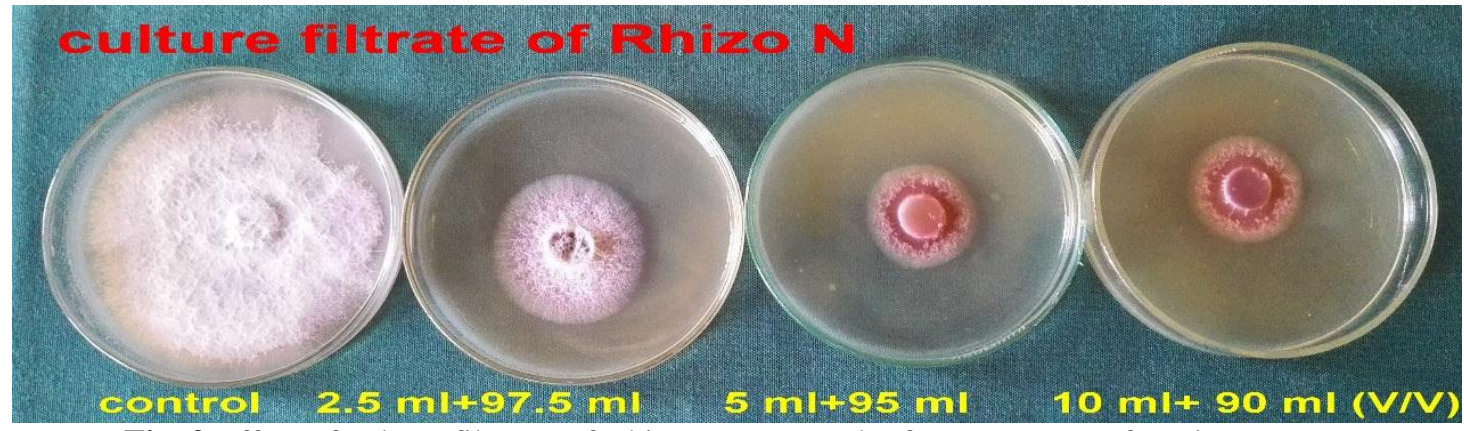

Fig. 9 Effect of culture filtrates of Rhizo-N on growth of $F$. oxysporum f. sp lycopersici.

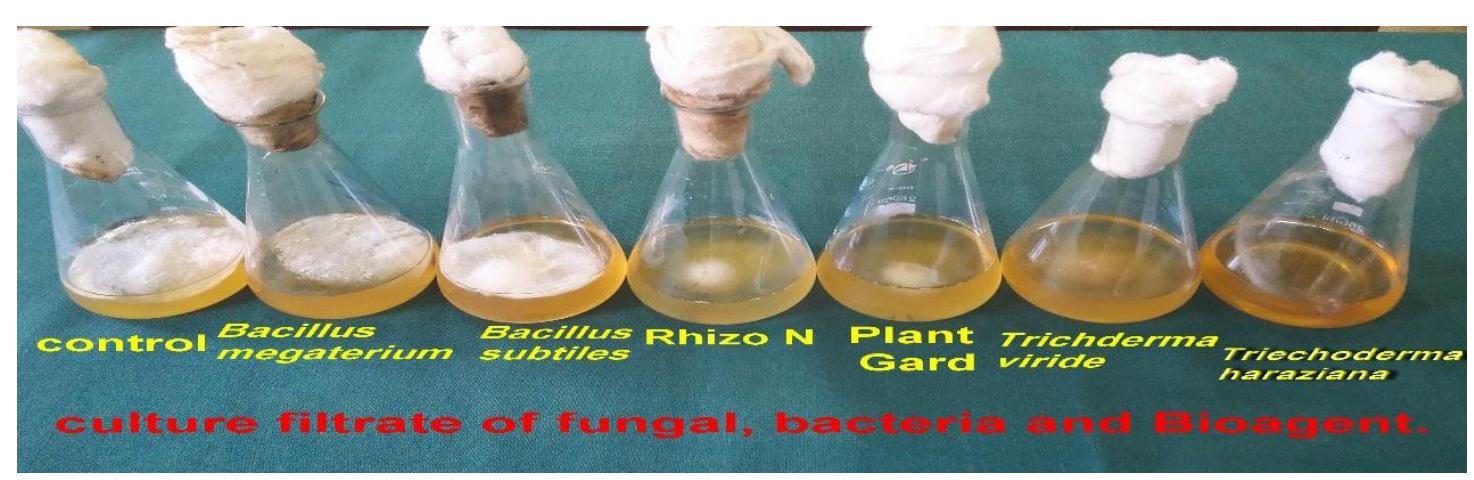

Fig. 10 Effect of culture filtrates of different bioagents on growth of $F$. oxysporum $\mathrm{f}$. sp lycopersici. on liquid media.

\subsection{Effect of culture filtrates of $F$. oxysporum $f . s p$} lucopersiscii on tomato seed germination and other botanical characters:

Data in Table (5) and Fig. (10 ) reveal a concentration of $10 \%$ free culture filtrates of the pathogenic fungus markedly reduced seed germination by about $30 \%$ if compared with control treatment (either sterile tap water or autoclaved filter sterile culture filtrate) indicating that culture filtrate is heat labile, hazardous and notorious.

As for other growth parameters, length of radical and hypocotyl were significantly reduced by culture filtrate. Positive relationship between the increase in culture filtrate and the increase in inhibition of radical 
and hypocotyl of germinating seeds which is considered to be a hazard cas

Table 5. Effect of cultural filtrates of $F$. oxysporum f.sp lycopersici on tomato seed germination and other botanical characters.

\begin{tabular}{cccccc}
\hline $\begin{array}{c}\text { Treatments } \\
\text { culture filtrate } \\
\text { Concentrations (\%) }\end{array}$ & $\begin{array}{c}\text { \% of } \\
\text { germination }\end{array}$ & $\begin{array}{c}\text { Growth } \\
\text { parameters } \\
\text { Length }(\mathbf{c m})\end{array}$ & $\begin{array}{c}\text { \% of } \\
\text { inhibition }\end{array}$ & $\begin{array}{c}\text { Growth } \\
\text { parameters } \\
\text { Length }(\mathbf{c m})\end{array}$ & $\begin{array}{c}\text { \% of } \\
\text { inhibition }\end{array}$ \\
\cline { 2 - 6 } Radical & Radical & Hypocotyl & Hypocotyl \\
\hline 2.5 & 100 & 1.32 & 60 & 2.14 & 46 \\
\hline 5 & 100 & 0.76 & 77 & 1.2 & 66 \\
\hline $\begin{array}{c}\text { Autoclaved fungal } \\
\text { filtrate }\end{array}$ & $\mathbf{7 0}$ & $\mathbf{0 . 0}$ & 100 & $\mathbf{0 . 8}$ & $\mathbf{8 0}$ \\
\hline Tap water & 100 & 3.29 & 0.0 & 3.94 & 0.0 \\
\hline L.S.D at 0.05\% & $\mathbf{0 . 0 0 1}$ & $\mathbf{0 . 1 5}$ & - & 0.13 & 0.0 \\
\hline
\end{tabular}

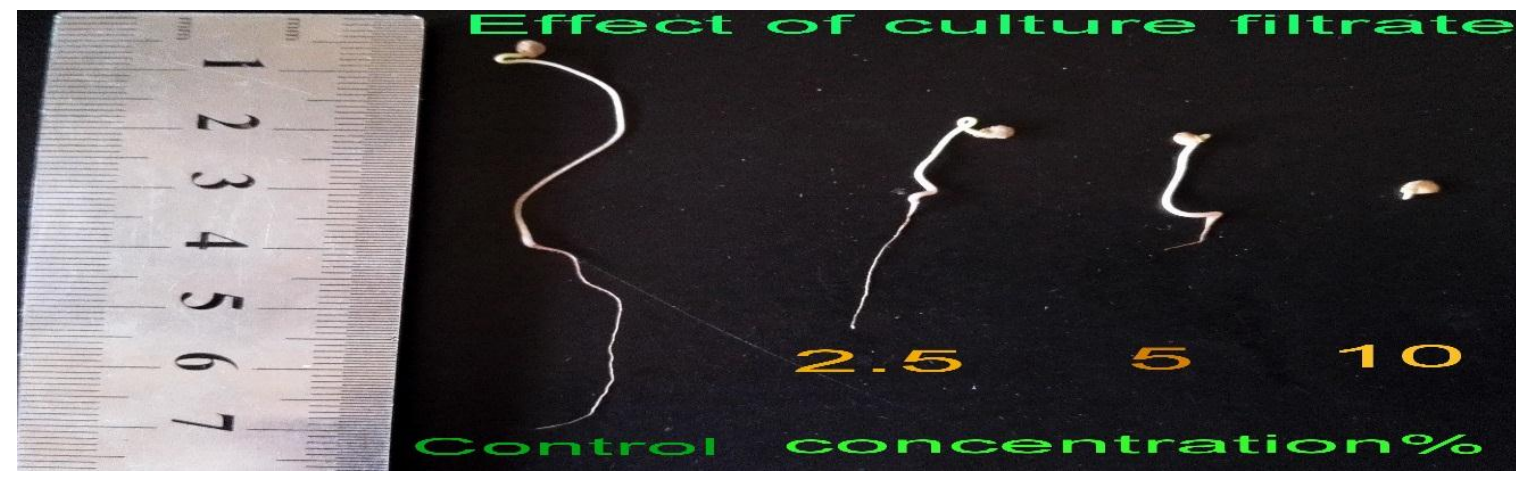

Fig. 11 Effect of some concentration of free culture filtrates of $F$. oxysporum f. sp lycopersici on tomato seed germination and other growth parameters.

\section{Discussion}

During the course of this investigation it has bee found that T. harzianum, T. viride, B. subtilis and $B$. megaterium which were isolated from the rhizosphere of naturally wilted tomato plants are promising bioagents in cotrolling the pathogenic fungus. These microorganisms showed strong antagonistic effect against the pathogenic fungus $F$. oxysporum $\mathrm{f}$. sp. lycopersici in vitro and in vivo. Application of the bioagents individually reduced the percentage of wilt disease of tomato. Furthermore, crud and sterile culture filtrates of the bioagents reduced fungal growth in vitro. Plant-Guard and Rhizo $\mathrm{N}$ also showed antagonistic effect in vitro and reduced disease severity in vivo. Monceren fungicide was used in vitro and in vivo and caused the inhibited growth in vitro and reduced disease severity under field conditions. Moreover ,The effect of the isolated bioagents surpassed in some cases in some cases the effect of Monserean fungicide and other used commercial products. The abovementioned results are in general agreement with those reported with $T$. harazianum, $T$. viride, B. subtilis and B. megaterium ( Riggle,1972, Change and Kommedahl, 1968,Sabry-Soha et al., 2016 and Magdy-Maryan, 2016 )

Recently, It has been found that B.s subtilis is a powerful biocontrol agent, since it is naturally present in the immediate vicinity of the plant roots and able to maintain stable contact with higher plants and promote their growth. In addition to its broad host range, its ability to form endospores and produce different biological active compounds with a broad spectrum of activity. B. subtilis and other Bacillus are potentially useful biocontrol agents.Non- pathogenic F.oxysporum successfully controlled pathogenic isolate of the fungus.Bacillus strain from rhizosphere of wilted tomato plants which has strong antagonistic effect in vitro against the pathogenic fungus $F$. oxysporum f.sp lycopersici used to control the fungus this may be due to production of protease, chitinase and lipase. The bacterium has antagonist effect against other phytopathogens ).(James etal., ,2007 Nagorska et al., 2007and Vanter etal 2013).

In this investing much attention was focused on the effect of culture filtrates of T.harzianum, T. viride, Plant-Guard, B. subtilis and B. megaterium and Rhizo$\mathrm{N}$ on fungal growth in vitro. Free culture filtrates also of the bioagents and commercial ones inhibited fungal growth in vitro. It was observed that with the increase of the concentration of the culture filtrates of the bioagent (Trichoderma or Bacillus) there was greater inhibition of the mycelial growth of the tested fungus. These findings are in close agreement with those reported before (Khan and Sinha, 2007; Ashwini and Shivakumar, 2012, Devi and Singh, 2012; Enespa and Dwivedi, 2014; Shafie-Radwa and El- 
Sharkawy, 2016 and Sabry-Soha et al., 2016). In this respect, Enespa and Dwivedi, 2014; found that free culture filtrates of $T$. harazianum, $T$. viride and $T$. longibrachianum inhibited the growth of $F$. solani by $48.91,84.01$ and $100 \%$ and $F$. oxysporum f. sp. lycopersici by $100,73.67$ and $100 \%$ respectively when incorporated in the medium at different concentrations

In this investigation, free culture filtrates of $F$. oxysporum f. sp.lycopersici reduced seed germination, root and hypocotyl length. These results are in general agreement with those reported with Lim et al., 1990; Idris et al., 2003 and Khurshid et al., 2014. Fungal toxin of $F$. oxysporum lycopersici are known to cause destruction of plant by causig necrosis, chlorosis, wilting and sometimes by inhibiting seed germination (Idris et al., 2003). Subsequently Khurshid et al., $\mathbf{2 0 1 4}$, found that culture filtrates of $F$. oxysporum $\mathrm{f}$. sp. lycopersici reduced seed germination and affected seedling growth and physiology of tomato. Germination, growth and biomass were significantly decreased by 40,85 and $70 \%$ due to original culture filtrates of the fungus therefore they are hazardous to tomato seedlings.

Sutherland and Pegg, 1990, reported that Fusaric acid stimulated rapid development of some disease such as interveinal necrosis and foliar dessication. Subsequently.

Antagonistic activity of three isolates of Trichoderma spp against Fusarium solani and F. oxysporum f. sp. lycopersici are due to parasitism competition and antibioses. Again coiling and penetration of antagonistic hypha of $T$. virens and $T$. harazianum around the hyphae of $F$. solani and their lysis and production of organic metabolites was also reported (Anwar et al., 2008).

In conclusion, the present study suggests that antagonists viz., T. harzianum, T. viride, B.subtilis and $B$. megaterium can be used as alternative to pesticide to minimize the wilt disease of tomato crop besides improving yield as they are environmentaly safe.

Beneficial microbes typically produce bioactive molecule that affect the interaction of plants with their pathogens. Many secondary metabolites may also have antibiotic properties which enable the producing microbe to inhibit or kill other microorganisms by competing for a nutritional niche (Vinale et al., 2014). Some of these compounds have been found to play an important role in plant disease by various beneficial microbes used world-wide for crop protection and biofertilization. These metabolites are toxic against plant pathogens and bio control-related metabolites may also increase disease resistance by triggering systemic plant defense activity and enhance root and shoot growth. Fungi belongs to the genus Trichoderma and bacteria belongs to the genus Bacillus are well known producers of secondary metabolites with a directivity against phytopathogens and compounds that substantially affect the metabolism of the plant. The wide scale application of selected metabolites to induce host resistant and to promote crop yield may become reality in the near future and represent a powerful tool for implementation of integrated pest management (IPM) strategies (Vinale et al 2014).

Fusarium wilt, Fusarium crown and root rot of tomato caused by $F$. oxysporum f. sp lycopersici and $F$. oxysporum f. sp radices-lycopersici respectively; continue to present major challenges for tomat crop (Mc Govern, 2015). Therefore, intensive research has led to an increased understanding of these diseases and their management. Recent researches in the management of Fusarium wilt ,Fusarium crown and root rot has focused on diverse individual strategies and their integration including host resistance, chemical, biological and physical control.

\section{References}

Ashwini, B. and Shivakumar, A. (2012). Multifarious antagonistic potentials of rhizosphere associated bacterial isolates against soil borne diseases of Tomato. Asian Journal Plant Science and Research, 2: 18

Chandel, S., Allan, E. J. and wooward, S. (2009). Biological control of Fusarium oxysporum f. sp lycopersici on tomato by Brevibaciillus bevis. Journal of phytopathology ,158:470-478.

Change, I. P. and Kommedahl, T. (1968). Biological control of seedling blight of corn by coating kernels with antagonistic microorganisms. Journal of Phytopathology, 58:1395-1401.

Datroff, L.E., Nemcc, S. and Pernezyn , K. (1995). Biological control of Fusarium crown and root rot of tomato in Florida using Trichoderma harazianum and Glomus intraradices . Biological conrol , 5: 427-431.

De Cal , A., Pascual , S. Larena ,I. and Melgarcjo, P.(1995) : Biological control of Fusarium oxysporum f. sp lycopersici. Journal of Plant Pathology, 44: 909-917.

Devi, T.N. and Singh, M.S. (2012). Evaluation of suitable fungicide for integration with Trichoderma isolates for the control of tomato wilt. Journal of Mycopathology, 50: 223-228.

Enespa and Dwivedi, S.K. (2014). Effectiveness of some antagonistic fungi and botanicals against Fusarium solani and Fusarium oxysporum f. sp. lycopersici infecting brinjal and tomato plants. Asian Journal of Plant Pathology, 8: 18-25.

Fokemmma, N.J. (1973). The role of saprophytic fungi in antagonism against Drechslera sorokiniana (Helminthosporium sativum) on agar plates and on rye leaves with pollen. Physiology Plant Pathology, 3: 195-205.

Fravel , D.R., Deahl, K.L. and Stommel, J. R. (2005). Compatibility of the biocontrol fungus Fusarium oxysporum strain CS20 with sected fungicides . Biological control, 34 : 165-16

Gomez, K.A. and Gomez, A.A. (1984). Statistical Procedures for Agricultural Research. John Wiley 
and Sons. Intersciences Publication, New York, U.S.A., p.p. 678.

Harman ,G. E., (2000). Myths and dogmas of biocontrol: changes in perception derived from research on Tricoderma harzianum T22. Plant Disease, 84: 377-393.

Idris, A.E.; Abouzeid, M.A.; Boari, A.; Vurro, M. and Evidente, A. (2003). Identification of phytotoxic metabolites of a new Fusarium sp. inhibiting germination of Strigaher monthica seeds. Journal of Phytopathology, 42: 65-70.

Jacobs, A.; Govender, R. and Van-Heeerden, S. (2013). Fusarium oxysporum f. sp lycopersici race 3 causing tomato wilt in South Africa. Australian Plant Disease, Notes, 8: 145-147.

James, R.; Kasten, D.A. and Dumroese, U.S. (2007). Potential for Using Fusarium to Control Fusarium Disease in Forest Nurseries. Journal of Proceedings RMRS, 50: 51-60.

Khan, A.A. and Singha, A.P. (2007). Screening of Trichoderma ssp. Against Rhizoctonia solani the causal agent of rice sheath blight. India phytopathology. 60: 450-456.

Khurshid, S.; Shoaib, A. and Javaid, A. (2014). In vitro toxicity evaluation of culture filtrates of Fusarium oxysporum f. sp. lycopersici on growth and physiology of tomato under chromium (VI) stress. Journal of Animal and Plant Science, 24: 1241-1245.

Larkin, R.P. and Fravel, D.R. (1998). Efficacy of various fungal and bacterial biocontrol organisms for control of Fusarium wilt of tomato. Plant Disease, 82: 1022-1028.

Lim, S.M.; Song, H.S. and Gray, L.E. (1990). Phytotoxicity of culture filtrates from Fusarium solani isolated from soybean. Journal of Phytopathology 80: 1044.

Magdy-Maryan, Z. (2016). Studies on cutting basal rot and root rot disease of rose plants. M.Sc. Thesis, Plant Pathology Department, Faculty of Agriculture Minia University, p.p. 1-132.

Mc Govern, R.I. (2015). Management of tomato disease caused by Fusarium oxysporum. Crop Production, 73: 78-92.

Ministry of Agriculture and Reclamation, Agriculture Research Center, Central Department for Agricultural Extension and Ecology (2015).

Nagórska, K.; Bikowski, M. and Obuchowski, M. (2007). Multicellular behavior and production of a wide variety of toxic substances support usage of Bacillus subtilis as a powerful bio control agent. Journal Act Biochimica Polonica, 54: 495-508.

Riggle, J . H. R (1972). Relelationnship of Erwinia herbicola to Erwinia amylovora . Candadian Journal Botany, 50 : 1077 - 1083.

Sabry-Soha, A.Z.; Abdel-Kader, D.A. and AbouZaid M.I. (2016). Biological control of Altrenaria brassiciola causing cabbage black leaf spots disease: $15^{\text {th }}$ Congress of Phytopathology, Management of Plant Disease for Sustainable. Agriculture Development. Programme (Abstracts, 10-11).

Saleh,O.I.(1997).Wilt;root rot and seed diseases of groundnut in El-Minia Governorate, Egypt. Egypt Journal of Phytopathology, 25:1-18.

Saleh , O.I . Gabr , M.A.Khalil , M.A. and Mohamed , E.I .(2016) : Molecular variations among some isolates of Fusarium oxysporum $\mathrm{f}$. sp lycopersiciand response of some tomato cultivars and plant to infection $.13^{\text {th }}$ congress of phytopathology , 10-11 May 2017, 6, Giza , Egypt .PP15.

Saleh, O.I. and Stead, D. (2003). Bacterial soft rot disease of pea in Egypt. Integrated control in protected crops, Mediterranean Climate IOBC WPRS Bulletin, 26: 115-120.

Shafie-Radwa, M. and El-Sharkawy, H.H. (2016). Inducing systemic resistance against cucumber mosaic virus CMV using Streptomyces sp.;15 Congress of Phytopathology, Management of Plant Disease for Sustainable Agriculture Development. Programme and Abstracts, 10-11 May 2016.

Sutherland, M.L. and Pegg, G.F. (1990). The basis of host recognition on Fusarium oxysporum $f$. sp. lycopersici. Physiological Molecular Plant Pathology, 40: 423-436.

Vanter,N.Pascal,K.and Ernest,S.(2013).Isolation Bacillus strain from the rhizosphere of tomotoand their in vitro antagonistic effect against phytopathogenic fungi .Journal of Microbiology, 2:56-71.

Vinale, F.; Sivasithamparam, K.; Ghisalberti, E.; Woo1, S.; Nigro, M.; Marra, R.; Lombardi, N.; Pascale, M.; Manganiello, S.G. and Lorito1, M. (2014). Trichoderma secondary metabolites active on plants and fungal pathogens. Mycology Journal, 1: 127-139. 


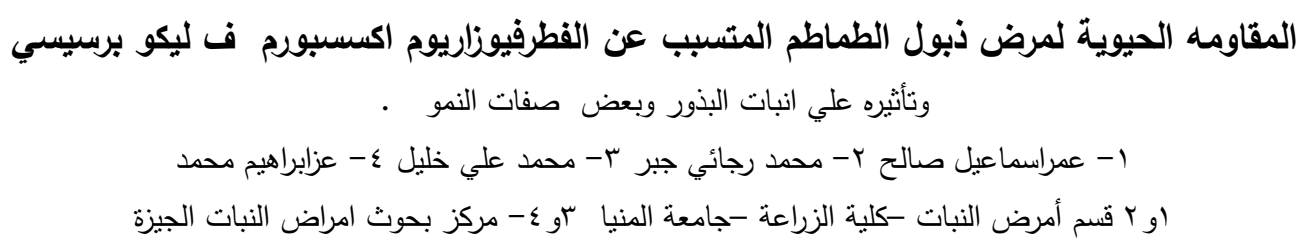

ثبت وتم في بحث سابق ان فطر الفطرفيوزاريوم اكسبورم ف ليكو برسيسي هو مسبب مرض ذبول الطماطم وفي هذا البحث تم محاولة مقاومة الفطر باستخدام القاومة الحيوية.تم عزل الفطرترايكودرما هارزيانم وترايكودرما فيريدي وكذللك البكتريا باسلس ساتلس وباسلس ميجاتريم من فن فئن ريزوسيرنباتات الطماطم المصابة طبيعيا بمرض الذبول. تم اثبات قدرة الفطريات المعزولة وكذلك البكتريا علي احداث تضاد للفطر المسبب للمرض في المبرل المعمل

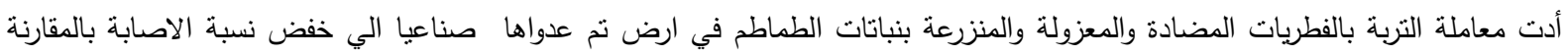
بالنباتات المنزرعة بالارض الغير معداة صناعيا .

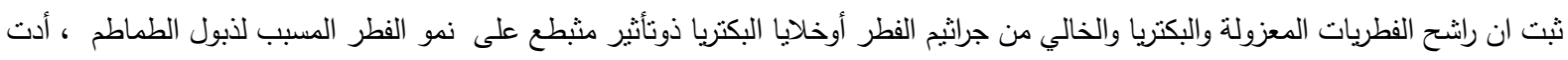
معاملة بذور الطماطم براشح الفطر المسبب للمرض الي خفض نسبة انبات البذوربنسبة .r\% كما ادي الي نقص كل من طول الجذير والسويقة الجنينية السفلي مما يدل علي ان راشح الفطر مصدرخطر علي نسبة الانبات وصفات نمو النبات. 
